\title{
Development of the prickly pear cactus Opuntia stricta (Haw.) Haw. (Cactaceae) in vitro in response to the replacement of potassium nitrate for a commercial $\mathrm{kno}_{3}$ fertilizer
}

\author{
Cinthia Carolinne de Souza Ferreira ${ }^{1^{*}}$ (i) Cristiane Domingos da Paz $^{2}$ (D) Joselita Cardoso de Souza ${ }^{2}$ (i) \\ Ana Rosa Peixoto ${ }^{2}$ (i) Lucas Silva Rios ${ }^{2}$ (i) Alessandro Rosa Nascimento ${ }^{2}$ (D) \\ Juliana Martins Ribeiro ${ }^{3}$ (i) Natoniel Franklin de Melo $^{3}$ (i) \\ Silvio Lopes Teixeira ${ }^{4}$ (D) Jairton Fraga Araújo ${ }^{5}$ (i)
}

\begin{abstract}
${ }^{1}$ Programa de Pós-graduação em Agronomia: Horticultura Irrigada (PPGHI), Universidade do Estado da Bahia (UNEB-C3), 48900-000, Juazeiro, BA, Brasil. E-mail: cinthiaagro@gmail.com. ${ }^{*}$ Corresponding author.

${ }^{2}$ Departamento de Tecnologia e Ciências Sociais, Universidade do Estado da Bahia (UNEB - C-3), Juazeiro, BA, Brasil.

${ }^{3}$ Embrapa Semiárido, Petrolina, PE, Brasil.

${ }^{4}$ Universidade Estadual do Norte Fluminense (UENF), Campos dos Goytacazes, RJ, Brasil

${ }^{5}$ Centro de Agroecologia, Energias Renováveis e Desenvolvimento Sustentável (CAERDS), Universidade do Estado da Bahia (UNEB - C3), Juazeiro, BA, Brasil.

ABSTRACT: In micropropagation, potassium nitrate $\left(\mathrm{KNO}_{3}\right)$ an ACS reagent grade chemical, used in the preparation of growing mediums is expensive and its procurement depends on bureaucratic procedures, as it is controlled by the Brazilian Army. This research to assessed the effect of replacing the $\mathrm{ACS} \mathrm{KNO}_{3}$ for a commercially available fertilizer ( $\mathrm{KNO}_{3}$ based) on the micropropagation of the prickly pear cactus (Opuntia stricta (Haw.) Haw. cv. Elephant Ear. Treatments used six different fertilizer concentrations (0, 0.5, $1,1.5,2$ and $\left.2.5 \mathrm{~g} L^{-1}\right)$ and a control consisting of $1.9 \mathrm{~g} \mathrm{~L}^{-1} \mathrm{KNO}_{3}$, as shown in the MS salts. The survival, size and number of sprouts and the value of fresh biomass were evaluated. After seedling acclimation, we assessed the survival, number of sprouts, length, and number of roots, racket formation, average fresh biomass mass, macronutrient absorption and morphological changes of the seedlings. Explants inoculated with fertilizers at concentrations of $0.0 ; 2.0$ and $2.5 \mathrm{~g} \mathrm{~L} \mathrm{~L}^{-1}$ did not grow. The response of explants at concentrations of 0.5 and $1.5 \mathrm{~g} \mathrm{~L}^{-1}$ of the fertilizer were the same as those developed in a $\mathrm{KNO}_{3}$ medium, and at a concentration of $1.0 \mathrm{~g} \mathrm{~L}^{-1}$, in all variables, the means were higher than those of the control medium. Therefore, it showed the feasibility of using fertilizers in the in vitro cultivation of the prickly pear cactus, which may remove bureaucratic barriers and reduce product costs by $99.12 \%$.
\end{abstract}

Key words: macronutrients, micropropagation, cost savings.

Desenvolvimento da palma Opuntia stricta (Haw.) Haw. (Cactaceae) in vitro em resposta à substituição de nitrato de potássio (P.A.) por fertilizante comercial $\mathrm{KNO}_{3}$

RESUMO: Na micropropagação, o nitrato de potássio $\left(\mathrm{KNO}_{3}\right)$, reagente puro para análise (P.A.), utilizado no preparo dos meios de cultura, possui custo elevado e a sua aquisição depende de trâmites burocráticos, por se tratar de substância controlada pelo Exército Brasileiro. O objetivo deste trabalho foi avaliar o efeito da substituição do $\mathrm{KNO}_{3}$ P.A. por fertilizante comercial (com fonte de KNO $\mathrm{K}_{3}$, encontrado livremente no comércio, na micropropagação de palma (Opuntia stricta (Haw.) Haw. cv Orelha de Elefante. Os tratamentos foram de seis concentrações do fertilizante $\left(0 ; 0,5 ; 1 ; 1,5 ; 2\right.$ e 2,5 $\left.\mathrm{g} \mathrm{L}^{-1}\right)$ e um controle constituído de $1,9 \mathrm{~g} \mathrm{~L}^{-1}$ de reagente $\mathrm{KNO}_{3}$, conforme mostrado nos sais MS. Avaliouse a sobrevivência, tamanho e número de brotações do explante, e o valor da biomassa fresca. Após a aclimatização das mudas avaliou-se a sobrevivência, número de brotações, comprimento da parte aérea, número de raízes, formação da raquete, massa média da biomassa fresca, absorção de macronutrientes e alterações morfológicas das mudas. Os explantes inoculados em meio com fertilizantes nas concentrações de 0,0; 2,0 e 2,5 $\mathrm{g} \mathrm{L}^{-1}$ não se desenvolveram. A resposta dos explantes nas concentrações de 0,5 e 1,5 $\mathrm{g} \mathrm{L}^{-1}$ do fertilizante foram iguais aos

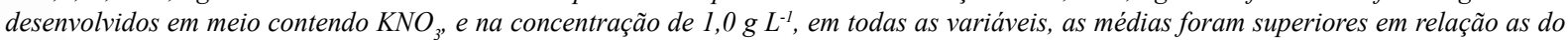
controle. Dessa forma, constatou-se a viabilidade do uso do fertilizante no cultivo in vitro da palma, o que propiciou a eliminação dos entraves burocráticos e redução no custo de 99,12\% na compra do produto.

Palavras - chave: macronutrientes, micropropagação, redução de custos.

\section{INTRODUCTION}

The cultivation of cactaceae has grown due to its high foraging capabilities and ornamental characteristics, such as varied shapes and sizes. The prickly pear cactus cv. Elephant Ear (Opuntia stricta Haw.) stands out among these species due to its high productivity, low nutritional requirements, tolerance to drought and resistance to carmine mealybug (Dactylopius opuntiae Cockerel), the main cause 
of damages to cacti (SILVA et al. 2015). It is widely used in arid and semi-arid regions (ZINGALE, 2016), where forage cactus represents an important asset for animal feeding. However, conventional propagation methods are insufficient to meet the commercial demand for seedlings in these regions (BHAU \& WAKHULU, 2015). Thus, micropropagation emerges as an alternative to obtain large-scale pest-resistant propagules.

In vitro cultivation enhances clonal propagation and accelerates genetic improvement of plant species, adding value to crops (GAVA \& LOPES, 2012). However, micropropagation is expensive due to the material used in the preparation of the growing medium and the need for appropriate equipment and facilities to perform the technique (WEBER et al. 2015). In order to reduce costs, research has been conducted to find different sterilization protocols such as chemical sterilization (PAIS et al. 2016), the removal or reduction of inorganic salts (CHEE \& POOL, 1987 and RIBEIRO \& TEIXEIRA, 2008), and the replacement of inaccessible reagents with others, more affordable and freely traded.

Among the reagents that make up the growing medium, potassium nitrate $\left(\mathrm{KNO}_{3}\right)$, a highpurity macronutrient, is used at a great extent and, in addition to the high price, is an Army-controlled substance. This reagent is key in the induction and differentiation process of the aerial part of the plant, playing both a structural and enzymatic activation role, acting as an osmoregulator (MALAVOLTA et al. (1997) and TAIZ \& ZEIGER, 2013). Replacing ACS $\mathrm{KNO}_{3}$ with easy-to-purchase and lower-cost products tends to be a promising alternative to make micropropagated seedlings viable, provided their toxic effect on the explant is duly assessed (RIBEIRO et al. 2013).

To reduce costs in the acquisition of growing medium components and eliminating bureaucratic procedures for the purchase of reagents, this paper assessed the replacement of $\mathrm{ACS} \mathrm{KNO}_{3}$ for a commercial fertilizer and its effect on in vitro and exogenous development of the prickly pear cactus Opuntia stricta (Haw.) Haw.

\section{MATERIALS AND METHODS}

The vegetable matter from the prickly pear cactus used as an explant donor came from the inventory culture of the Embrapa Biotechnology Laboratory, Semi-arid, Petrolina, PE (0904'16,4” S, $\left.040^{\circ} 19^{\prime} 5,37^{\prime \prime} \mathrm{W}\right)$. The plants were maintained for 120 days in a growth room with a 16-hour photoperiod, temperature of $25 \pm 2{ }^{\circ} \mathrm{C}$ and light intensity of 40 $\mu \mathrm{mol} \mathrm{m}{ }^{2}$. The nutrient medium consisted of inorganic MS salts (MURASHIGE \& SKOOG, 1962).

In vitro development was assessed at different concentrations of granular $\mathrm{KNO}_{3}$ trade name Dripsolin (chemical composition $\left(45 \% \mathrm{~K}_{2} \mathrm{O}, 12 \% \mathrm{~N}\right.$ and $1.2 \% \mathrm{~S}$ ) in the growing medium, replacing the ACS reagent. We used the concentrations $0.5,1.0 ; 1.5$; 2.0 and $2.5 \mathrm{~g} \mathrm{~L}^{-1}$ of the fertilizer and for control purposes, we used $\mathrm{ACS} \mathrm{KNO}_{3}\left(1,9 \mathrm{~g} \mathrm{~L}^{-1}\right)$, as a reagent, in a total of seven treatments. The different concentrations were based on calculations of the chemical formulation in proportion to the ACS reagent.

The nutrient medium consisted of inorganic MS salts (MURASHIGE \& SKOOG, 1962), and White vitamins (WHITE, 1943). The medium was supplemented with $0.1 \mathrm{~g}$ inositol, $30 \mathrm{~g} \mathrm{~L}^{-1}$ sucrose, 1.5 $\mathrm{mg} \mathrm{L}^{-1}$ of 6 benzylaminopurine (BAP), $0.0625 \mathrm{mg} \mathrm{L}^{-1}$ naphthalene acetic acid (ANA) and $5 \mathrm{~g} \mathrm{~L}^{-1}$ agar as a gelling agent. The $\mathrm{pH}$ was adjusted to $5.9 \pm 1$ and the medium was sterilized by autoclaving $\left(121{ }^{\circ} \mathrm{C}\right.$, $1.05 \mathrm{~kg} \mathrm{~cm}^{2}$ for 20 minutes). After the preparation, $20 \mathrm{~mL}$ of the growing medium was distributed into containers glasses (50 $\mathrm{mm}$ x $200 \mathrm{~mm}$ ).

Transverse segments of approximately 3 $\mathrm{mm}$ were placed in the growing medium and kept in the growth room at the Biotechnology Laboratory of the State University of Bahia $\left(09^{\circ} 25^{\prime} 43.6^{\prime \prime}\right.$ S, 40 32' 14 " W, $384 \mathrm{~m}$ ), at a temperature of $27 \pm 1^{\circ} \mathrm{C}, 16$-hour photoperiod and irradiance of $19 \mathrm{~mol} \mathrm{~m}^{-2} \mathrm{~s}^{-1}$.

In vitro development was evaluated by counting the average number of shoots, the average number of shoots greater than or equal to two centimeters and the average value of fresh biomass. During the acclimatization, plants developed in vitro were transplanted to disposable cups $(200 \mathrm{~mL})$ filled with commercial substrate, identified according to each treatment and kept in a greenhouse with $75 \%$ shading. They were manually irrigated every four days. On the $35^{\text {th }}$ day, plants were assessed with regard to the average number of shoots, average length of root and shoot, formation of cladode, average value of fresh biomass. In order to quantify the absorption of macronutrients according to the methodology proposed by Silva et al. (2009), we took a composite sample of each treatment. The seedlings were placed in five-liter plastic pots, filled with commercial substrate to allow the observation of morphological characteristics of the adult plant, and supposed changes due to the different dosages of potassium nitrate.

The experiment was conducted in a randomized design with seven treatments, five replications and three experimental plots. Count data 
were into $\sqrt{x+0.5}$ in order to meet the statistical assumptions, submitted to a variance analysis, and when proven significant $(\mathrm{P}<0.05)$, the means were compared by the Tukey test at a $5 \%$ significance, using the Statistica software, version .8.0.

\section{RESULTS AND DISCUSSION}

Prickly pear cactus explants in a medium containing fertilizer at concentrations of $0.0 ; 2.0$; and $2.5 \mathrm{~g} \mathrm{~L}^{-1}$ did not survive. Therefore, we were able to assess only plants obtained from treatments with concentrations of $0.5 ; 1.0$ and $1.5 \mathrm{~g} \mathrm{~L}^{-1}$ of commercial fertilizer and compared to explants developed in a medium containing the ACS reagent $\left(1.9 \mathrm{~g} \mathrm{~L}^{-1}\right)$, as a control treatment. Treatments with a growing medium containing 0.5 and $1.0 \mathrm{~g} \mathrm{~L}^{-1}$ of commercial fertilizer had a higher yield of shoots and shoots $\geq 2 \mathrm{~cm}$ than the control treatment (ACS $\mathrm{KNO}_{3}$ ). Regarding the average value of fresh biomass, the control treatment 1.0 $\mathrm{g} \mathrm{L}^{-1}$ provided the highest value, while other treatments did not differ from the control treatment (Table 1).

In general, fertilizer dosages used in the preparation of the growing medium promoted responses on the explants of prickly pears cactus equal to or higher than those developed in the medium containing the ACS reagent. However, it should be noted that the $1.0 \mathrm{~g} \mathrm{~L}^{-1}$ fertilizer concentration resulted in higher values of all variables assessed. After $35^{\text {th }}$ days of acclimatization, the plants showed the same responses in different concentrations of $\mathrm{KNO}_{3}$ fertilizer in relation to the average length of the aerial part, average length of the root (MRL) and average formation of rackets / cladodes (ARI). As for the average number of sprouts (ANS) and average value of fresh biomass (FAVA), concentrations of 0.5 and 1.0 $\mathrm{g} \mathrm{L}^{-1}$ produced higher values when compared to those obtained in treatments 1.9 (control treatment) and 1.0 $\mathrm{g} \mathrm{L}^{-1}$ media (Table 2). During the acclimatization period, the plants adapted to the environment and showed a similar development; although, the seedlings were originated from micropropagation in growing mediums with different $\mathrm{KNO}_{3}$ concentrations The palm grew evenly and on day 20 , the racket became expressive in the plants that went through the different treatments assessed, showing no morphological abnormality during its establishment. Leaf analysis allowed to ascertain macronutrient absorption, as a function of the different concentrations and source of $\mathrm{KNO}_{3}$ (Table 3). The pace of nutritional absorption under the conditions proposed in the experiment was in the following ascending order: $\mathrm{P}<\mathrm{Mg}<\mathrm{Ca}<\mathrm{N}<\mathrm{K}$.

Nitrogen is featured exclusively in the form of cation and anion (ammonium andnitrate, respectively) and is key in the performance of plant metabolic activities and absorption of other nutrients from the environment (REZENDE et al., 2008). It also directly influences the development of plants and, when in inappropriate quantities, may be highly harmful. (SASAMORI et al. 2016). Thus, the death of prickly pear explants, grown in a growing medium with $0 ; 2.0$ and $2.5 \mathrm{~g} \mathrm{~L}^{-1}$, may have been caused by the absence or excess of nitrogen in the form of nitrate, reported in the commercial fertilizer. However, fertilizer concentrations of 0.5 to $1.0 \mathrm{~g} \mathrm{~L}^{-1}$ added to the growing medium resulted in a good in vitro development of the prickly pear cactus, due to its low nutritional requirements, thus confirming the nutritional information of this species as assessed by LOPES et al. (2010), and this behavior is also observed in ex vitro growth. Thus, in order to reduce micropropagation costs, it is advised to use the smallest

Table 1 - Influence of different sources and potassium nitrate concentrations in the in vitro development of the prickly pear cactus Opuntia stricta (Haw.) Haw. cv. Elephant ear.

\begin{tabular}{|c|c|c|c|c|}
\hline $\begin{array}{l}\mathrm{KNO}_{3} \mathrm{~g} \mathrm{~L}^{-1} \\
\text { Concentration }\end{array}$ & Surviving cultures $\%$ & ANS & $\mathrm{ANS} \geq 2$ & AVFB \\
\hline 1.9 (MS) & 100 & $2.05 b$ & $1.33 b$ & $1.56 \mathrm{~b}$ \\
\hline 0.5 & 100 & $3.06 \mathrm{a}$ & $2.31 \mathrm{a}$ & $1.81 \mathrm{~b}$ \\
\hline 1.0 & 100 & $3.04 \mathrm{a}$ & $2.49 \mathrm{a}$ & $3.91 \mathrm{a}$ \\
\hline 1.5 & 100 & $1.83 b$ & $1.37 \mathrm{~b}$ & $2.56 \mathrm{~b}$ \\
\hline $\mathrm{CV}$ & & 19.43 & 20.05 & 34.81 \\
\hline
\end{tabular}

Averages followed by the same letter do not differ statistically from each other according to the Tukey test at a 5\% probability; MSsalts (MURASHIGE \& SKOOG, 1962); ANS - average number of shoots (cm); ANS $\geq 2 \mathrm{~cm}$, average number of shoots greater than or equal to two cm; AVFB - average value of fresh biomass; CV - coefficient of variation. 
Table 2 - Influence of different sources and potassium nitrate $\mathrm{n}$ the ex vitro development of the Prickly Pear Opuntia stricta (Haw.) Haw. cv. Elephant ear.

\begin{tabular}{|c|c|c|c|c|c|c|}
\hline $\mathrm{KNO}_{3}$ & Surviving Cultures & ANS & CMPA & ARF & MRL & AVFB \\
\hline $\mathrm{gL}^{-1}$ & $\%$ & & $\mathrm{~cm}$ & $\mathrm{~cm}$ & $\mathrm{~cm}$ & G \\
\hline 1.9 (MS) & 100 & $1.84 \mathrm{~b}$ & $11.9 \mathrm{a}$ & $2.43 \mathrm{a}$ & $5.50 \mathrm{a}$ & $15.96 \mathrm{~b}$ \\
\hline 0.5 & 100 & $2.62 \mathrm{a}$ & $10.44 \mathrm{a}$ & $2.19 \mathrm{a}$ & $6.50 \mathrm{a}$ & $28.34 \mathrm{a}$ \\
\hline 1.0 & 100 & $2.41 \mathrm{a}$ & $9.34 \mathrm{a}$ & $1.97 \mathrm{a}$ & $4.68 \mathrm{a}$ & $25.89 \mathrm{a}$ \\
\hline 1.5 & 100 & $1.82 \mathrm{~b}$ & $9.60 \mathrm{a}$ & $2.30 \mathrm{a}$ & $5.27 \mathrm{a}$ & $16.75 b$ \\
\hline $\mathrm{CV}$ & & 18,28 & 25,75 & 25,85 & 30,08 & 19,41 \\
\hline
\end{tabular}

Averages followed by the same letter do not differ statistically from each other according to the Tukey test at a 5\% probability; MSsalts (MURASHIGE \& SKOOG,1962); ANS - average number of shoots (cm); ANS $\geq 2 \mathrm{~cm}$ - average number of shoots greater than or equal to two cm; CMPA - average shoot length (cm); ARF - average racket formation (cm); MRL - mean root length (cm); AVFB average value of fresh biomass $(\mathrm{g})$; $\mathrm{CV}$ - coefficient of variation.

amount of fertilizer, which meets the nutritional needs of the in vitro culture of the prickly pear without changing the physiological behavior under acclimatization and post-acclimatization conditions. The use of low concentrations does not change the macronutrient absorption process, such as nitrogen, phosphorus, potassium, calcium, magnesium, thus not interfering in the metabolic processes (TAIZ and ZEIGER, 2013). Considering the high proportion of $\mathrm{KNO}_{3}$ in the ACS growing medium, the high cost and unavailability of nitrogen salts, there are some ongoing studies on alternative methods to make the micropropagation technique viable. KURITA \& TAMAKI (2014) and SASAMORI et al. (2016), achieved a good development of bromeliads, when they reduced the amounts of salts and nitrogen compounds of the in vitro ACS medium. SOUSA et al. (2006) tested the reduction of ammonium nitrate and potassium nitrate in the micropropagation of coffee (Coffea arabica L. cv Rubi), and the best results were achieved in explants inoculated in a growing medium with $50 \%$ ammonium nitrate and $75 \%$ of potassium nitrate. Similar results were achieved by REZENDE et al. (2008), in the same coffee variety (Rubi), grown in vitro, in which the highest shoot growth occurred with the lowest concentrations of potassium nitrate and this development pattern was maintained in acclimatized plants. The result of reducing potassium nitrate concentration of the ACS medium in the in vitro culture of these crops is similar to the results reported for the prickly pear cactus. Under the conditions tested in this analysis, the lower $\mathrm{KNO}_{3}$ concentrations $(0.5$ and $1.0 \mathrm{~g} \mathrm{~L}^{-1}$ ), which corresponds to a 26.3 and $52.6 \%$ reduction, respectively, led to the highest growth under both in vitro and ex vitro conditions. Results showed that the reduction of potassium nitrate provides greater development, confirming that adjusting the salt concentrations of the ACS medium improves the quality of the resulting seedlings and also provides a cost reduction in the in vitro propagation. In addition to reducing inorganic salts, the replacement for more affordable products, eliminating bureaucratic and less

Table 3 - Influence of different sources and potassium nitrate concentrations on the nutritional absorption of in vitro micro propagated prickly pears Opuntia stricta (Haw.) Haw.

\begin{tabular}{|c|c|c|c|c|c|c|c|}
\hline Concentrations & $\mathrm{Ca}^{+2}$ & $\mathrm{Mg}^{+2}$ & $\mathrm{~K}+$ & $\mathrm{P}$ & $\mathrm{NH}^{+4}$ & $\mathrm{NO}^{-3}$ & Total N \\
\hline $\mathrm{KNO}_{3}$ & $\left(\mathrm{~g} \mathrm{~kg}^{-1}\right)$ & $\left(\mathrm{g} \mathrm{kg}^{-1}\right)$ & $\left(\mathrm{g} \mathrm{kg}^{-1}\right)$ & $\left(\mathrm{g} \mathrm{kg}^{-1}\right)$ & $\left(\mathrm{g} \mathrm{kg}^{-1}\right)$ & $\left(\mathrm{g} \mathrm{kg}^{-1}\right)$ & $\left(\mathrm{g} \mathrm{kg}^{-1}\right)$ \\
\hline $1.9(\mathrm{PA})^{\mathrm{ns}}$ & 1.43 & 0.24 & 9.10 & 0.004 & 0.46 & 4.72 & 5.18 \\
\hline 0.5 Fertilizer $^{\mathrm{ns}}$ & 1.32 & 0.24 & 10.10 & 0.002 & 0.58 & 4.83 & 5.41 \\
\hline 1.0 Fertilizer ${ }^{\mathrm{ns}}$ & 1.15 & 0.19 & 11.02 & 0.002 & 0.55 & 2.97 & 3.52 \\
\hline 1.5 Fertilizer ${ }^{\mathrm{ns}}$ & 1.11 & 0.16 & 10.01 & 0.002 & 0.51 & 2.83 & 3,34 \\
\hline
\end{tabular}

The absorption rate was in an ascending order: $\mathrm{P}<\mathrm{Mg}<\mathrm{Ca}<\mathrm{N}<\mathrm{K}$. $\mathrm{ns}=$ The results did do not differ statistically. 
expensive procedures, can be a promising alternative. VILLA et al. (2009), studied the possibility of inserting urea in the ratios of $0 ; 20 ; 40 ; 60 ; 80$ and $100 \%$ in comparison to ACS ammonium nitrate in the micropropagation of the Blackberry (Rubus rubus) cv Tupy. In the absence of salt, plants yielded the highest amount of leaves, but plants developed in a medium with urea amounts higher than $20 \%$ presented reduced plant heights, number of leaves and fresh biomass, due to the resulting phytotoxicity. In the micropropagation of the pernambuco pineapple, urea was used at a concentration of $40 \%$, replacing ACS ammonium nitrate, confirming the feasibility of the partial or total replacement of the agent, promoting a better plant development in a solid growing medium (MOREIRA et al., 2007). This response is associated with the nutritional specificity and phenological stage of each plant species in the absence of potassium nitrate. The prickly pear explants did not survive, as other plant species, such as the Hypericum teretiusculum A.St.Hil, wherein the reduction of nitrogenous compounds in the ACS growing medium harmed the development of plants (CAMPELO et al., 2020). RIBEIRO \& TEIXEIRA (2008) tested the reduction and replacement of ACS $\mathrm{KNO}_{3}$ for another fertilizer - potassium saltpeter - in the in vitro cultivation of Brazilian ginseng (Pfaffia glomerata), thus achieving a biomass increase. In this research, we obtained similar results in the in vitro and ex vitro cultivation of the prickly pear cactus, since its seedlings showed good development during and after acclimatization, maintaining a pattern and uniformity during growth. Regarding the nutrient absorption rate in the prickly pear cactus, SANTOS et al. (1990) reported an ascending order at the end of the production cycle: $\mathrm{N}<\mathrm{P}<\mathrm{K}<\mathrm{Ca}$. When propagated in a medium with different proportions of $\mathrm{KNO}_{3}$ (ACS Reagent and granular fertilizer), the absorption rate was in an ascending order: $\mathrm{P}<\mathrm{Mg}<\mathrm{Ca}<\mathrm{N}<\mathrm{K}$. Different absorption rates may be due to different physiological requirements throughout the development phases of the plant. Plant samples in this research were collected on the $35^{\text {th }}$ day, under acclimatization conditions. Considering the development of the prickly pear cactus, under the conditions proposed for this paper, changing the ACS reagent for a commercial fertilizer is a promising alternative, since the acquiring ACS potassium nitrate $\left(\mathrm{KNO}_{3}\right)$ in Brazil is subject to the army's authorization (Ordinance $\mathrm{N}^{\circ}$. 118, 2019). Another feature that enhances the use commercial fertilizers as a viable alternative for potassium and nitrogen supply instead of the ACS reagent is the similar chemical composition $\left(45 \% \mathrm{~K}_{2} \mathrm{O}, 12 \% \mathrm{~N}\right.$ and
$1.2 \% \mathrm{~S})$ and the ACS reagent $\left(44 \% \mathrm{~K}_{2} \mathrm{O}\right.$ and $13 \%$ $\mathrm{N})$. Therefore, replacing $\mathrm{KNO}_{3}(\mathrm{ACS})$ minimizes the costs of setting a growing medium, as the current price of fertilizers is approximately $\mathrm{R} \$ 170.20$ each $25 \mathrm{Kg}$, while the ACS reagent costs R\$780.00. The replacement resulted not only in a $99.12 \%$ cost reduction, but also eliminated procurement issues, as the purchase of fertilizer does not need to be authorized by the Armed Forces. When compared to the ACS medium protocol, a smaller proportion of commercial fertilizer $\left(0.5\right.$ to $\left.1.5 \mathrm{~g} \mathrm{~L}^{-1}\right)$ was enough to achieve the in vitro development and maintaining the ex vitro growth for the prickly pear cactus.

\section{CONCLUSION}

The $1.0 \mathrm{~g} \mathrm{~L}^{-1}$ concentration of a potassium nitrate-based fertilizer promoted the best growth response in the prickly pear cactus cv. Elephant Ear, both in and ex vitro, when compared to the ACS reagent. Replacing an ACS potassium nitrate reagent $\left(\mathrm{KNO}_{3}\right)$ for a similar commercial fertilizer is a promising alternative to the micropropagation of the prickly pear cactus cv. Elephant Ear, reducing costs of purchasing this reagent by $99.12 \%$ and eliminating paperwork.

\section{ACKNOWLEDGMENTS}

Cinthia Carolinne de Souza Ferreira thanks to Coordenação de Aperfeiçoamento de Pessoal de Nível Superior Brasil (CAPES) - finance code 001.

\section{DECLARATION OF CONFLICT OF INTEREST}

The authors declare no conflict of interest. The founding sponsors had no role in the design of the study; in the collection, analyses, or interpretation of data; in the writing of the manuscript, and in the decision to publish the results.

\section{AUTHORS' CONTRIBUTIONS}

All authors contributed equally to the design and writing of the manuscript.

\section{REFERENCES}

BHAU, B. S.; WAKHLU, A. K. A highly efficient in vitro propagation protocol for elephant tusk cactus: Coryphantha elephantidens (Lem.) Lem. Journal of Genetic Engineering and Biotechnology, v.13, n.2, p. 215-219, 2015. Available from: $<$ https:// www.sciencedirect.com/science/article/pii/S1687157X1500030X >. Accessed: Nov. 27, 2019. doi: 10.1016/j.jgeb.2015.07.003.

CAMPELO, M. R. et al. Effects of different concentrations of ammonium nitrate and potassium nitrate on the micropropagation of two species of Hypericum $l$. Brazilian Journal of 
Development, v.6, n.11, p.85050-85056, 2020. Available from: $<$ https://www.brazilianjournals.com/index.php/BRJD/article/ view/19364/15543>. Accessed: Nov. 27, 2019. doi: 10.34117/ bjdv6n11-063.

CHEE, R.; POOL, R. M. Improved inorganic media constituents for in vitro shoot multiplication of Vitis. Scientia Horticulturae, v.32, n.1-2, p.85-95, 1987. Available from: <https://www.sciencedirect. com/science/article/abs/pii/0304423887900197>. Accessed: Nov. 10, 2019. doi: 10.1016/03044238(87)90019-7.

GAVA, C. A. T.; LOPES, E. B. Produção de mudas de palma forrageira utilizando fragmentos de cladódios. Petrolina: Embrapa Semiárido, Np. (Embrapa Semiárido. Instruções Técnicas, 101), 2012. Available from: <https://www.infoteca.cnptia.embrapa.br/ bitstream/doc/930562/1/INT101.pdf >. Accessed: Nov. 17, 2019.

KURITA, F. M. K., TAMAKI, V. In vitro growth of the bromeliad Alcantarea imperialis (Carrière) Harms with different concentrations of nitrogen. Acta Scientiarum. Biological Sciences, v.36, n.3, p.279-285, 2014. Available from: <http://www.periodicos.uem. br/ojs/index.php/ActaSciBiolSci/article/view/22933>. Accessed: Nov. 30, 2019. doi: 10.4025/actascibiolsci.v36i3.22933.

LOPES, E. B. et al. Selection of cactus pear forage (Opuntia spp.) And (Nopalea spp.) Genotypes resistant to the carmine cochineal (Dactylopius opuntiae Cockerell, 1929) in the state of Paraíba, Brazil. Engenharia Ambiental Pesquisa e Tecnologia, v.7, n.1, p.204-215, 2010. Available from: <https://pdfs.semanticscholar.org/8251/8d97ae f3dfeec651aafb1620901f438eeb05.pdf>. Accessed: Dec. 6, 2019.

MALAVOLTA, E. et al. Avaliação do estado nutricional das plantas: princípios e aplicações, 1997.

MINISTÉRIO DA DEFESA EXÉRCITO BRASILEIRO COMANDO LOGÍSTICO PORTARIA N ${ }^{\circ} 118$ - COLOG, DE 4 DE OUTUBRO DE 2019. EB: 64447.041399/2019 - 31 Available from: $<$ http://portalsfpc.2rm.eb.mil.br/files/cr/pj/Portaria $\% 20$ n $\%$ C2 $\%$ BA $\% 20$ 118COLOG\%2C\%20de \%204\%20Out $\% 202019 \% 20-\% 20$ Lista $\% 20$ de\%20PCE\%20\%281\%29.pdf>. Accessed: Nov. 6, 2019.

MOREIRA, M. A. et al. Micropropagation of pineapple cv. Pérola with urea as nitrogen source. Acta Scientiarum. Agronomy, v.29, p.689-693, 2007. Available from: <http://www.scielo. br/scielo.php? pid $=$ S1807-86212007000500015\&script $=$ sci arttext\&tlng=pt $>$. Accessed: Nov. 30, 2019. doi: 10.4025/ actasciagronv29i5.748.

MURASHIGE T, SKOOG F. A revised medium for rapid growth and bio assays with tobacco tissue cultures, Physiol. Plant. v.15, n.3, p.473-497, 1962. Available from: <https://onlinelibrary.wiley. com/doi/abs/10.1111/j.1399-3054.1962.tb08052.xt>. Accessed: Sep. 10, 2019. doi: 101111/j.13993054.1962.tb08052.x.

PAIS, A. K. et al. Sodium hypochlorite sterilization of culture medium in micropropagation of Gerbera hybrida cv. Essandre. African Journal of Biotechnology, v.15, n.36, p.1995-1998, 2016. Available from: <https://www.ajol.info/index.php/ajb/ article/view/144461>. Accessed: Nov. 2, 2019. doi: 10.5897/ AJB2016.15405.

REZENDE, J. C. et al. Development of Coffea arabica L. seedlings obtained from direct somatic embryogenesis. Coffee Science, v.3, n.1, p.30-37, 2008. Available from: <http://sbicafe.ufv.br/ handle/123456789/5635>. Accessed: Dec. 5, 2019. doi: 10.25186/ cs.v3i1.70.
RIBEIRO, J. M. et al. Use of panela as nutritive medium for in vitro culture of banana cv. Maçã. Ceres, v.60, n.5, p.722-725, 2013. Available from: <http://www.scielo.br/scielo.php?pid=S0034737X2013000500017\&script=sci_arttext $>$. Accessed: Dec. 5, 2019 doi: 10.1590/S0034737X2013000500017.

RIBEIRO, J. M; TEIXEIRA, S. L. Potassium nitrate substitution for potassic saltpetre on preparation of plant tissue culture nutritive media esterilized with sodium hypochlorite. Ciência e Agrotecnologia, v 32, n.4, p.1209-1213, 2008. Available from: $<\mathrm{http}: / /$ www.scielo.br/scielo.php?pid=S141370542008000400026\&script $=$ sci_arttext\&tlng=en>. Accessed: Dec. 10, 2019. doi: 10.1590/S1413-70542008000400026.

SANTOS, M.V. F. et al. Estudo comparativo das cultivares de palma forrageira "Gi-gante", "Redonda" (Opuntia fcus-indicaMill) e "Miúda" (Nopalea cochenilliferaSalm-Dick) na produção de leite. Revista da Sociedade Brasileira de Zootecnia, v.19, n.6, p.504-511, 1990. Available from: <hhttps://www.cabdirect.org/ cabdirect/abstract/19921445564>. Accessed: Dec. 6, 2019.

SASAMORI, M. H. et al. Low macronutrient concentrations benefit in vitro propagation of Vriesea incurvata (Bromeliaceae), an endemic species of the Atlantic Forest, Brazil. Rodriguésia, v.67, n.4, p.10711081, 2016. Available from: <http://www.scielo.br/scielo.php? $\mathrm{pid}=\mathrm{S} 217578602016000401071 \&$ script $=$ sci_arttext\&tlng $=\mathrm{pt}>$. Accessed: Dec. 6, 2019. doi: 10.1590/21757860201667417.

SILVA, F. C. D. S. et al. Manual de análises químicas de solos, plantas e fertilizantes (Vol. 627). Brasília: Embrapa Informação Tecnológica; Rio de Janeiro: Embrapa Solos, 2009. SILVA, T. G. F. et al. Crescimento e produtividade de clones de palma forrageira no semiárido e relações com variáveis meteorológicas. Revista Caatinga, v.28, n.2, p.10-18, 2015. Available from: <https://periodicos.ufersa.edu.br/index.php/ caatinga/article/view/3630>. Accessed: Dec. 6, 2019.

SOUSA C. M. et al. Otimização da concentração dos sais do meio MS na propagação in vitro de gérbera, var. 'Ornela'. Agronomia, v.40, p.52-58, 2006. Available from: <http://www.ia.ufrrj.br/ revista/Vol.\%2040\%20-2006/DPF/Trab.\%20008\%20-.pdf>. Accessed: Nov. 6, 2019.

TAIZ, L.; ZEIGER, E. Fisiologia vegetal. 5. ed. Porto Alegre: Artmed, p.918, 2013.

VILLA, F. et al. Utilização de nitrato de amônio e de uréia como fontes de nitrogênio na micropropagação de amoreira-preta. Scientia Agraria, v.10, n.5, p.365-370, 2009. Available from: $<$ https://www.redalyc.org/pdf/995/99512493004.pdf >. Accessed: Dec. 12, 2019. doi: 10.5380/rsa.v10i5.15192.

WEBER, B.N. et al. Low-Cost potato tissue culture with microwave and bleach media preparation and sterilization. The Potato Association of America, v.92, n.1, p.128-137, 2015. Available from: <https://link.springer.com/article/10.1007/s12230-014-94237>. Accessed: Oct. 12, 2019. doi: 10.1007 / s12230-014-9423-7.

WHITE, P.R. Nutrient deficiency studies and an improved inorganic nutrient medium for cultivation of excised tomato roots. Growth, v.7, p.53-65, 1943.

ZINGALE, N. Tecniche innovative di propagazione e di caratterizzazione di specie e varietà di Opuntia e generi affini. Doctoral Thesis dc. publisher. Università di Catania, 2016. Available from: <http://dspace.unict.it:8080/handle/10761/4091>. Accessed: Dec. 12, 2019. 